\section{PALI BUDDHIST IDEAS ABOUT THE FUTURE ${ }^{1}$}

\section{Steven Collins ${ }^{2}$}

\begin{abstract}
This article surveys ideas of the futurespecifically whether it will be (i) worse, (ii) the same, or (iii) better, for individuals and/or society -in the Pali imaginaire, a corpus of texts produced and circulated in the agrarian states of premodern South and Southeast Asia and which survives as a resource for Buddhists in the vastly changed conditions of the modern, globalized world.
\end{abstract}

In considering ideas found in Pali texts, as indeed in any texts, we must not only think about the ideas they contain, but the conditions of the world in which they were composed and transmitted. The Pali imaginaire was the product of a premodern, pre-industrial world, which could not envision continuous technological progress leading to a materially better life and/or ecological

\footnotetext{
${ }^{1}$ This paper was originally given as a talk at Chulalongkorn University in 2001. It is based on my book Nirvana and Other Buddhist Felicities (Collins 1998), where references to Pali texts and secondary scholarly literature can be found. To suggest where to look, I will give here the chapter headings of the book: 1. The Concept of Nirvana. 2. The Imagery of Nirvana. 3. Nirvana, Time and Narrative. 4. Heaven, the Land of Cockaygne and Arcadia. 5. Millennialism. 6. The Perfect Moral Commonwealth? Kingship and its Discontents. 7. The Vessantara Jätaka. ${ }^{2}$ Professor, Department of South Asian Languages and Civilizations, University of Chicago.
}

devastation which modern people take for granted. It could, and did, envisage futures better than the present, but these would be in heaven, or in a future world where wishing-trees would supply all the consumer goods then thought possible. In both cases the better future was in a fantasy world where many material and other pleasures would be available, but where the production of material goods, and therefore of society and culture, would not itself undergo any fundamental, qualitative change. There might be an increase in the amount of good things but not in the capacity of human beings and their world to produce new categories of good. In particular, no future would be without the hierarchical, class-divided social orderdivided into tribute-givers and tributetakers - in which all imagining took place. Some modernists have thought to see a classless society in an episode in the Aggañña Sutta, reproduced many times in other texts. Here immaterial beings fall to life on earth, gradually become material, and then exist for a short time before theft and the need for punishment bring about authority, hierarchy and then the four varna-s of Brahmanical society. This was taken to recur at the start of every eon. I think it can be shown that this whole text is a satirical allegory rather than the description of any actual society; ${ }^{3}$ but even if that is not granted, it remains a brief tobe-abandoned episode, not a continuing state of human society.

These basic, categorial changes in the production of human goods and of human culture have taken place, whether we like it or nor, and they have irrevocably affected

\footnotetext{
${ }^{3}$ See Collins (1993a). The sutta quite clearly and deliberately uses language from the Vinaya: each 'fall' from immaterial to material/social life involves transgressing against one or more Vinaya rules.
} 
all premodern systems of ideas. Some things, of course, have stayed the same: sexual and family relations, suffering, the inevitability of death. Modernity has not done away with the aporias intrinsic to thinking about time without paradox. In monotheism, for example, the problems arise of conceiving time as having a beginning and end: what did God do before he created time, and what can anyone do after it stops? Do not tensed verbs such as "created" and "stops" presuppose a matrix of time in order to have their meaning? Pali texts do not have these problems: since everything except nibbāna exists through the process of conditioning, there can be no absolute beginning to samsāra. And although individual streams of conditioning and consciousness can end in nibbāna, the universe, being infinite, cannot end. The aporia in Pali texts, at least as I understand it, concerns the relation between time and dhamma-s, those momentary, conditioned and conditioning events, or collections of events, which temporarily make up the world and ourselves. Time is not a dhamma, a real existent; rather it occurs in dependence on real existents (dhamme upādāya). It has no sabhāva, nothing which defines it as an existent separate from others. However, the concept of a dhamma seems itself to presuppose time: no dhamma can exist without previous conditions, elaborated into twenty-four causal factors (paccaya) in Abhidhamma and other texts. Although some of a dhamma's causal factors can be simultaneous with its arising, they could not all be, or else the universe would be just one moment. So, time is not a real existent but arises in dependence on real existents, while the real existents themselves seem already to need time as a conceptual and interpretative framework.

Such aporetic questions have little to do with the task of doing good and cleansing one's heart, ${ }^{4}$ though they may induce a salutary humility. Perhaps there are some things human beings will never understand. Small advances in other matters related to time may be possible, however, and I believe one of them comes from completely abandoning what has become a taken-forgranted cliché: the cyclical time of the east versus the linear time of the west. This originated with early Christians, who foisted on the Greeks a view of so-called cyclical time to which they could oppose their linear time - in fact their obsession with a single story - with a once-and-for-all creation, redemption and end of the universe. In fact there is no clear evidence that any Greek held such a view. With one exception all the evidence comes from Christian writers themselves, and for good reason: while it is possible to believe that events recur in time, even that exactly the same events recur, it cannot make any sense to say that time itself recurs. If one says "everything happens again," the word "again" presupposes time; there will always be something different, even if it is merely the fact that things are happening for a second, third, umpteenth time. This Christian illogical rhetoric was carried down through the centuries; and when Europeans discovered Asian beliefs in rebirth, they seemed to slip neatly into the "cyclical time" category.

All moments in time have both linear and cyclical aspects, and the choice between them depends on one's purposes and interests. I suspect that most people reading this sentence are doing so for the first time. This moment is unique and irrecoverable, a

\footnotetext{
${ }^{4}$ The reference is to Dhammapada 183 .
} 
station on a one-way train trip from birth to death. But it is just another article in just another journal. It has probably been read before now, and may well be again. Nothing can be done that has not been done, unless one makes the necessary uniqueness of linear time an over-riding dimension. Dropping the first nuclear bomb, Neil Armstrong standing on the moon, computer scientists in the 1990s working on the Y2K problem - all firsts, in some senses, but just think for a moment and previous analogies easily come to mind.

So when one tries to think about ideas of the future in Pali texts written in the premodern era, one must bear in mind how much has changed, how much has stayed the same, and how much is part of the human condition and not a specificity of tradition. In considering the future, one can think of it as worse than the present, same as the present, or better than the present. And one can think of it in relation just to oneself, or to society or humanity as a whole.

\section{The future will be worse.}

A. for the individual. The possibility of a worse future for the individual can be found on innumerable temple walls, in the form of paintings of hell taken from the Traiphum tradition, and the story of Māleyya (Phra Malai). ${ }^{5}$ Who can forget the boiling cauldrons, the misshapen, sometimes half-human half-animal, creatures whose grotesquely large heads are cut in two by whirling serrated metal wheels, the terrified adulterers forced at spear-point to climb the thorn tree? In the Ussada hell, for instance, victims' tongues

${ }^{5}$ See Reynolds and Reynolds (1982), Collins (1993b). are pierced by red-hot iron hooks, and then they are dragged around, before being spread out like ox-hides on a red-hot copper floor, to be further attacked with stakes. Versions of these texts and stories have circulated in manuscripts, books, posters and postcards, and in three-dimensional form in temple grounds and theme parks.

B. for society. There are three ways in which society would get worse, two of which we know a lot about, while the other has not been studied fully. The first is the Disappearance of the Sāsana after 5000 years. For many centuries now kings and others have announced that they were doing this or that, notably sponsoring the writing down of the Tipitaka, for the sake of the longevity of the Sāsana, to contribute to its 5000 -year life. This is too well-known to need elaboration, as is the second: the gradual deterioration of human society until it becomes a seven-day war of all against all, apart from wise few who meditate in caves, dressed in white, to re-emerge after the carnage to begin society anew. This originates from the Cakkavattisinanāda Sutta and continues to appear on temple walls in the modern period sometimes with the addition of aerial warfare. The third is the notion that time moves in a sequence of Four Ages, starting with the Age of Truth (Satya-yuga) and ending with our own, the worst, called the Age of Kali (Kali-yuga), which will come to an end in huge conflagration. Very little is known about the real history of this idea. The idea of a conflagration at the end of the eon is found in Pali texts, and so too, in commentarial and later texts, is the term Kali-yuga for our eon. A great deal more work is necessary before we can understand the origin and influence of this notion. It is true, in any case, that although most of the universe will be destroyed, not all of it will, and after some time another Age of Truth will begin. 
Premodern Buddhism was spared one modern scenario of the future: destruction of the environmental conditions necessary for human life, without a guarantee that it will re-arise somewhere.

\section{The future will be the same.}

A. for the individual. It seems hardly likely that the maintenance of the status quo would be an object of aspiration in a Buddhist perspective.

What do you think, monks? Which is more? Your shedding and crying of tears as you have hurried on through this long road of rebirth, tied to what is unpleasant and separated from what is pleasant, or all the water in the Four Great Oceans?

[They answer: greater are the tears we have shed.]

Good, good, monks. You have well understood the Doctrine as I have taught it.... For a long time you have experienced the death of your mother,... of your sons,... daughters, the loss of relatives and possessions, the distress of disease.... For such a long time, monks, you have experienced suffering, feeling pain and enduring distress; and the cremation grounds and cemeteries grow...

(Samyutta Nikāya II: 179-80, Anamatagga Samyutta Sutta 3)

This could well express resignation at the human condition for those with little hope of heroics - up and down, around and around on the carousel of samsāra-but scarcely an ambition.
B. for society. In one vital sense, mentioned above, hierarchical agrarian society was a given for the entire Pali imaginaire in premodernity. That could not change. Rich man, poor man, beggar, thief-individuals playing each role as lives passed by. In another sense too, if one ignores changes in individual destiny, the matrix of future time must resemble the present, in that it will contain the appearance and disappearance of Buddhas. The historicism inherent in modern scholarship has affected modernist Buddhism, and indeed all modern Buddhism which seeks to incorporate historical consciousness, so there tends in such contexts to be a focus on the person called in languages which have definite and indefinite articles, the Buddha, i.e. Siddhattha Gotama. It is, moreover, true that those texts preserved as the Tipitaka have extremely few references to past and future Buddhas by name. This has led some to think that multiple Buddhas are a later development. But references to Buddhas in the plural are everywhere in the Vinaya and Sutta texts, and it would be impossible plausibly to compile a list of allegedly earlier texts which refer only to Gotama. The true extent and significance of orientation towards future Buddhas in both traditional and modern Buddhism remains to be assessed.

\section{The future will be better.}

A. for the individual. Aspirations to a better future life in the human or divine worlds have always been at the center of the Buddhist imaginaire. It is sometimes thought in western scholarship that there is a contradiction between aspiring to heaven, or to better rebirth as a human, and to nirvana. There is indeed a Buddhist conceptual point to support this: craving and attachment to anything are inimical to the attainment of nirvana, and so if better 
rebirths give rise to those mental states, they too are part of the problem of suffering, not the solution. But a straightforward and all-pervasive dichotomy is bad psychology and bad cultural history. They are all aspirations to felicity, the celestial, and still more so, the human, with more color and content, nirvana with finality. It is no surprise that many texts see both heaven and nirvana equally as results of merit (puñ̃a). It is always easier to imagine suffering in detail than happiness, and so representations of life in heaven, whether in texts or painting, are much fewer than those of hell. Those that exist depict places of jewels, precious stones, beautiful sounds, colors, and perfumes. Deities live in vimāna-s, which both resemble palaces surrounded by lakes and trees, and move around. They enjoy the pleasures of the five senses, but those pleasures are sensual rather than sexual.

B. for society. It is not surprising, rather the reverse, that there is no sense in premodern Pali texts that human society could be categorically better, in the material sense. There are narrative fantasies of societies in which, under a righteous king, there is no crime, or wishing-trees bestow all manner of goods, or sometimes both. In the story of the future Buddha Metteyya, he co-exists with the Wheel-turning King Sankkha. Some other, minor instances of the coexistence of two such Great Men can be found, but it is only in relation to Metteyya that the salvific utopia of a Buddha is conjoined with the material utopia of a Wheel-turning King. In this respect, as others, the time of Metteyya will be an improvement on that of Gotama, and so the term Millennialism may be appropriately used. Rebirth at the time of Metteyya, usually with the corollary of attaining nirvana then, has often been associated with the ritual practice of listening to recitations of the Vessantara Jattaka. Both in this regard and elsewhere, being reborn with Metteyya has long been a common object of aspiration. Sometimes, as with king Dutthhagāminī in the Mahåvamsa, death in this world can lead both to immediate rebirth with Metteyya in the Tusita heaven, and future rebirth with him in the human world.

Such is a short overview of ideas about the future found in Pali texts. It is unclear what will become of them. In so far as they are dependent on the old pre-scientific cosmology, they must fade, or undergo allegorical re-interpretation. This has already been the case with the very idea of rebirth. Aspirations to future betterment in the modern world are inescapably tied to development and nationalism, and this is happening differently in the different conditions where premodern Pali texts are still a significant resource: with the Dalits in India, in Sri Lanka, Burma, Thailand, Cambodia, Laos, and southern Yunnan. The 1950s, for example, saw the Burmese Road to Socialism mixed traditional Buddhist ideas with Marxism, looking towards loka-nibbāna, nirvana in this world. Fifty years later, alas, Burma has become hell in this world for many people. The contemporary revival of Buddhism in Yunnan, after the devastation of the Cultural Revolution, is in part a vehicle to re-assert local values against the BeijingHan majority. In this project it co-operates and sometimes contrasts with western youth culture and popular music. In this case, as also in Cambodia, Buddhist ideas of the future are also part of a rediscovery and re-creation of the past.

In the Pali imaginaire, the possibility of nirvana has been central to all hopes for the 
future. This too, along with rebirth, has sometimes been subject to allegorical reinterpretation. Traditionally, although nirvana is not describable in terms of space or time, it enters the temporal process by being the object of consciousness at different stages of the Path. So while aspirations to nirvana are usually cast in the mold of future verbs, it is, so to speak, all around us in (rather, not in) space and time in a $360^{\circ}$ sphere. Pragmatically, therefore, the issue is not so much whether or not to anticipate it, but whether or not one can see it, now.

\section{References}

Collins, S. 1993a. "The Discourse on What is Primary (Aggañña Sutta)." Journal of Indian Philosophy 21: 301-93.

---. 1993b. "The Story of the Elder Māleyya." Journal of the Pali Text Society 18: 65-96.

---. (1998). Nirvana and other Buddhist Felicities: Utopias of the Pali Imaginaire. Cambridge: Cambridge University Press.

Reynolds, F.E., and M.B. 1982. Three Worlds according to King Ruang. Berkeley Buddhist Studies Series 4. Berkeley: University of California Press. 